\title{
Penyuluhan Ilmu Pengetahuan dan Teknologi Tepat Guna Dalam Meningkatkan Ekonomi Desa di Kabupaten Kepulauan Meranti
}

\author{
Syawaldi ${ }^{*}$, Kurnia Hastuti ${ }^{1}$
}

1Program Studi Teknik Mesin, Fakultas Teknik, Universitas Islam Riau, Jalan Kaharuddin Nasution 113, Pekanbaru, Riau, Indonesia - 28284

*Penulis koresponden: syawaldi@eng.uir.ac.id

\begin{tabular}{l} 
Info Artikel \\
\hline Riwayat: \\
Dikirim 20 April 2020 \\
Diterima 30 April 2020 \\
Dipublikasi 8 Mei 2020 \\
\hline
\end{tabular}

\section{Kata Kunci :}

Ekonomi masyarakat

Mandiri

Meranti

Pemberdayaan

Teknologi

\begin{abstract}
Abstrak
Kegiatan Pengabdian kepada masyarakat yang berjudul Ilmu Pengetahuaan dan Teknologi Tepat Guna (TTG) telah dapat dilaksanakan dengan baik dan sesuai dengan target yang dirapkan. Dimana kegiatan pengabdiaan kepada masyarakat dilaksanakan 18 - 20 Oktober 2019. Kegiatan pengabdian kepada masyarakat adalah kerjasama dengan Badan Pemberdayaan Masyarakat dan Desa. Dimana Universitas Islam Riau melalui Fakultas merasa terpanggil dalam rangka mencerdaskan masyarakat tentang ilmu pengetahuan teknologi tepat guna (TTG). Ilmu pengetahuan teknologi tepat guna merupakan hal yang sangat penting dalam pembangunan dan ekonomi pedesaan. Salah satu desa Bina Maju Kecamatan rangsang barat Kabupaten Kepulauan Meranti, dimana potensi sumber daya alam dan sumber sangat baik. Maka dari itu perlu membangun kreativitas dalam upaya untuk bisa bertahan dimasa yang akan dating. Salah satunya ilmu pengetahuan dan teknologi tepat guna salah satu alternatif untuk menyelesaian masyarakat di Desa saat ini. Selain itu, pembangunan dan ekonomi pedesaan yang berdasarkan usaha masyarakat perlu dimotivasi dan dikembangkan melalui teknologi berupa teknologi tepat guna. Untuk pengembangan teknologi tepat guna perlu upaya dan kerja masyarakat membuat teknologi tepat guna yang sesuai dengan potensi yang ada dimasyarakat itu sendiri. Maka dosen teknik mesin Fakultas teknik universitas islam riau bekerjasama dengan badan pemberdayaan masyarakat dan desa (PMD) kepulauan meranti memberikan pengajaran tentang ilmu pengetahuan teknologi tepat guna. Dengan tujuan kedepannya dapat meningkatkan sumber daya manusia (SDM) dalam pembuatan teknologi tepat guna untuk meningkatkan ekonomi masyarakat dan desa.
\end{abstract}

\section{PENDAHULUAN}

Untuk memanfaatkan peluang dan keuntungan posisi geografis dan mendorong pertumbuhan ekonomi wilayah perbatasan dengan negara tetangga Malaysia dan Singapura, maka wilayah kabupaten Kepulauan Meranti sangat potensial berfungsi sebagai Gerbang Lintas Batas Negara/Pintu Gerbang Internasional yang menghubungan dengan Riau daratan dengan negara tetangga melalui jalur laut, hal ini untuk melengkapi kota Dumai yang terlebih dahulu ditetapkan dan berfungsi sebagai kota Pusat Kegiatan Strategis 
Negara yaitu yang berfungsi sebagai beranda depan negara, pintu gerbang internasional, niaga dan industri.

Dalam rangka mencapai tujuan pembangunan nasional, desa merupakan agen pemerintah terdepan yang dapat menjangkau kelompok sasaran riil yang hendak disejahterakan. Maka harus semakin meningkatkan pengetahuan tentang teknologi pada era teknologi dan digital ini, supaya bisa dimanfaatkan dalam menciptakan produk baru, yang berguna bagi kehidupan bermasyarakat (Khusnawati \& Prasetyo, 2016). Semakin kedepan, daya saing dalam menciptakan produk semakin meningkat dan berdaya saing. Untuk itu, seluruh pihak juga harus menyesuaikan, supaya bisa mengembangkan perekonomian dan mensejahterakan masyarakat desa di Kepulauan Meranti.

Pembangunan fisik yang selama ini masih menjadi prioritas utama pemerintahan desa harus segera diubah. Kucuran dana desa yang setiap tahunnya semakin bertambah banyak harus juga dimanfaatkan untuk sektor pemberdayaan sumber daya manusia (SDM) juga. Kenapa demikian, seringkali pembangunan fisik seperti ini kurang bisa menjawab kebutuhan peningkatan kesejahtraan ekonomi. Bahkan parahnya lagi seringkali justru salah sasaran. Pentingnya Pemberdayaan SDM. Visi pemberdayaan SDM bisa dikatakan sebagai salah satu prioritas utama yang kini memang sedang digenjot oleh pemerintah pusat. Terlebih lagi dalam upaya untuk mewujudkan penguatan ekonomi pedesaan. pemerintah daerah beserta partisipasi masyarakatnya dan dengan menggunakan sumberdaya yang ada harus memanfaatkan potensi sumberdaya yang mempunyai nilai tambah jual dalam membangun perekonomian daerah (Arsyad, 1999). Salah satunya adalah dengan adanya Teknologi Tepat Guna (TTG), dimana dengan adanya kehadiran TTG dapat meningkatkan perekonomian masyarakat di Pedesaan (Rahmiyati, 2015).

Kecamatan Rangsa Barat berada sebelah utara Selat Malaka, dan Selatan Kecamatan Tebing Tinggi Barat \& Kecamatan Tebing Tinggi, Sebelah Barat Kecamatan Pulau Merbau, dan Timur oleh Kecamatan Rangsang Pesisir. Sebagian besar penduduknya masih tergantung pada kegiatan pertanian sawah, dan perkebunan seperti kopi, kelapa, buah-buahan dan pinang. Kecamatan ini bisa menjadi pusat pemasaran hasil pertanian dan perkebunan. Dari hasil survey daerah ini sudah beransur-ansur beralih fungsi seperti perumahan, hal diakibatkan masyarakat bertambah banyak tinggal di daerah ini. Sementara hasil pertanian akan berkurang, dan aktivitas masyarakat dalam mempertahankan kehidupan dimasa yang akan datang juga tidak terkoordinir. Sehingga ajumlah prosentase angka kemiskinan semakin tinggi dari data sekarang yaitu 27,79\% (Angka tertinggi di seluruh kabupaten/Kota Provinsi Riau pada tahun 2018) (Statistik, 2019).

Masalah yang akan timbul, jika daerah rangsang barat tidak dikelola dengan baik terutama sumber daya manusia, maka akan terjadi kedepan desa yang tidak memiliki aktivitas dan meningkatkan angka kemiskinan. Salah satu tantangan yang muncul dalam meningkatkan ekonomi Desa adalah kurangnya minat masyarakat untuk berkreativitas dan membudayakan Teknologi Tepat Guna, sehingga ini akan mengakibatkan munculnya masyarakat miskin yang berkelanjutan. Untuk Fakultas Teknik dan Lembaga Pengabdian Kepada Masyarakat merasa terpanggil untuk ikut serta memberikan masukan dan pemberdayaan masyarakat di daerah ini Rangsang Barat Kebupaten Kepulauan Meranti khususnya memberi bekal ilmu pengetahuaan dan Teknologi Tepat Guna.

\section{METODE PELAKSANAAN}

Pengabdian masyarakat ini dilaksanakan di Desa Bina Maju Kecamatan Rangsang Barat Kabupaten Kepulauan Meranti kerjasama dengan Dinas Pemberdayaan dan Desa 
(BPMD) dilaksanakan tanggal 18-20 Oktober 2019. Metode pelaksanaan kegiatan pengabdian kepada masyarakat adalah sebagai berikut:

1. Menghubungi kepala dinas Badan Pemberdayaan Masyarakat Kabupaten Kepulauan Meranti untuk menentukan dan mendiskusikan judul dan Sasaran dan Tepat pelaksanaan kegiataan.

2. Membuat surat pernyataan kesediaan Dinas Pemberdayaan Pada masyarakat dan Desa (BPMD) untuk kerjasama dalam kegiatan pengabdian kepada masyarakat dengan Program Studi Teknik Mesin Fakultas Teknik Universitas Islam Riau.

3. Dinas Pemberdayaan Masyarakat dan Desa mengarahkan ke Desa Bina Maju Kecamatan rangsang Barat.

4. Persiapan alat dan bahan yang akan digunakan dalam penyuluhan dan alat yang akan diserah terima nantinya.

5. Berangkat dari pekanbaru ke Button, dari button ke kepulauan Meranti (menginap), besok teruskan perjalanan Kecamatan Rangsang Barat menuju Desa Bina Maju.

6. Menyelenggarakan pelatihan dengan tahapan sebagai berikut :

a. Ilmu Pengetahuan Teknik (Perhitngan/Inovasi Suatu Teknologi Tepat Guna).

b. Pentingnya Teknologi Tepat Guna (TTG) di Desa.

c. Meningkatkan keterampilan dengan pembuatan produk TTG yang sesuai dengan kebutuhan di Desa.

7. Kembali Ke Kepulauan Meranti (menginap), Besok Kembali kepekanbaru.

\section{HASIL DAN PEMBAHASAN}

Kegiatan pengabdian kepada masyarakat ini dilaksanakan dalam bentuk ceramah, diskusi, pelatihan dan pemutaran vidio. Metode ceramah diperlukan untuk penyampaian informasi tentang ilmu pengetahuan yaitu Daya Mesin, Putaran Mesin, Puli dan sabuk, Rantai dan sprocket), faktor-faktor yng mempengaruhi Teknologi Tepat Guna (TTG), pentingnya cara pembuatan Teknologi Tepat Guna. Diskusi dilaksanakan untuk membahas permasalahan yang dihadapi peserta posyantek dalam melayani informasi Teknologi Tepat Guna seta menjadi ajang tukar pengalaman. Pemutaran vidio sangat bermanfaat sehingga peserta lebih memahami topik yang sedang dibahas dan secara visual peserta melihat berbagai jenis Teknologi Tepat Guna (TTG) yang ada di Indonesia dan di luar. Susunan Acara kegiatan Pengabdian Kepada Masyarakat adalah:

1. Sambutan Kepala Dinas Badan Pemberdayaan Masyarakat dan Desa.

2. Sambutan dari Kepala Desa Bina Maju Kecamatan Rangsang Barat.

3. Sambutan dari Ketua Posyantek yang mewakili unsur Masyarakat.

4. Penyerahan:
a. Alat Pengiris Ubi
b. Alat Pembelah Buah Pinang
c. Cendra Mata Dari Universitas Islam Riau

Sebelum dilaksanakan penyuluhan kegiatan Pengabdian Kepada Masyarakat di Kantor Desa Bina Maju. Kegaiatan dilakukan acara pembukaan seperti pada gambar 1. Terlihat Tim Penyuluhan Kepala Dinas, Kepala Desa dan Peserta pelatihan. Selanjut diteruskan kegiatan penyerahan bantuan alat-alat kepada kepala dinas BPMD dan Kepala desa serta kenangankenangan dari Universitas Islam Riau seperti terlihat pada gambar 2 dan 3. 
Buletin Pembangunan Berkelanjutan

Vol. 4 No. 1, April 2020 hal. 22-27

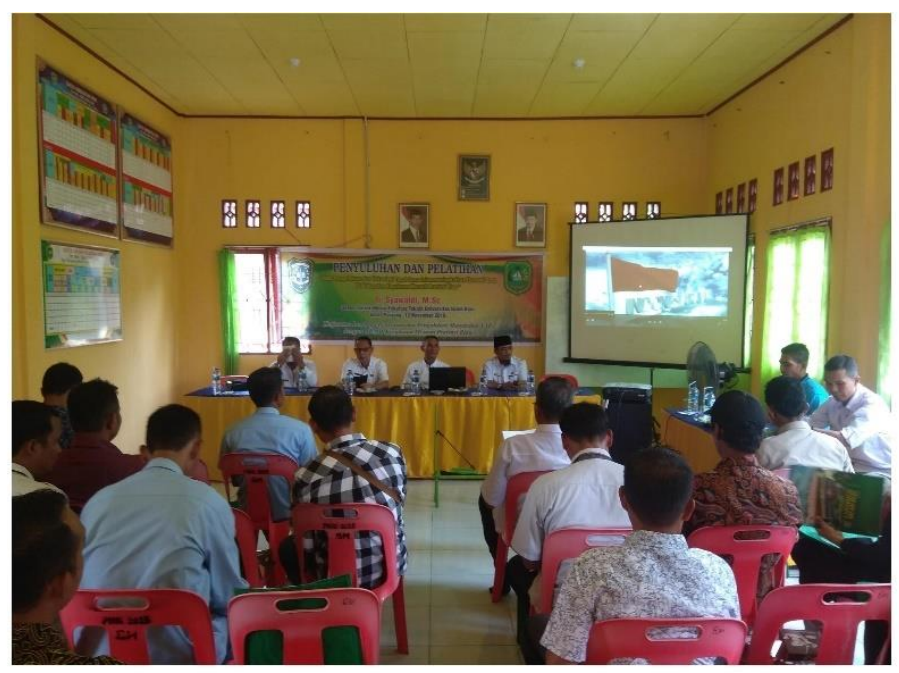

Gambar 1. Acara pembukan pelatihan

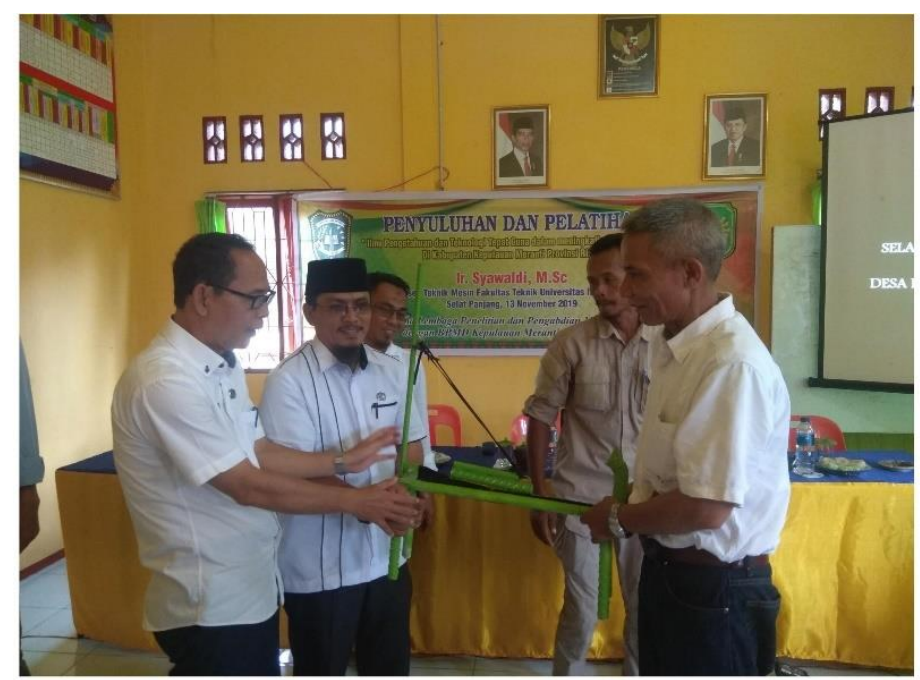

Gambar 2. Acara serah terima alat TTG (Pembelah Buah Pinang)

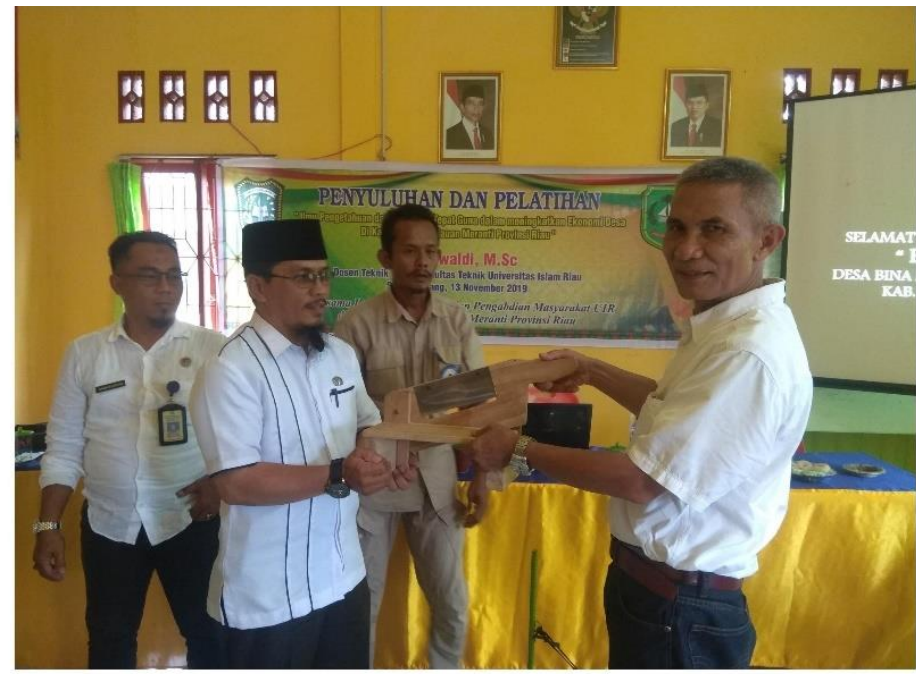

Gambar 3. Acara penyerahan bantuan alat TTG (Pengiris Ubi)

Kegiatan Pengabdian Kepada Masyarakat yang dilaksanakan selama 1 hari terdiri dari:

1. Materi menjelaskan tentang: 
a. Komponen-komponen alat teknologi dan fungsi alat.

b. Fungsi komponen alat pendukung.

c. Fungsi komponen alat pendukung.

d. Putaran Motor (rpm).

e. Menentukan daya dan putaran motor.

f. Perngelasan dan penyambungan.

g. Alat-alat penerus daya dan putaran (puli dan sabuk, rantai dan sprocket, roda gigi, gear box) daan lain-lain.

2. Diskusi dan tanya jawab

Pada kegiatan diskusi banyak antusias peserta bertanya, terutama tentang cara menghitung dan membuat alat. Selanjutnya juga mereka belum banyak mengetahui cara menentukan ukuran pemasangan alat dan komponen- komponen yang diperlukan. Sehingga dalam pelaksanaan waktu tidak cukup, karena keterbatasan waktu dan jarak yang jauh.

3. Demontrasi alat

Masyarakat diajarkan cara penggunaan alat pengiris ubi dan pemotong/pembelah buah pinang. Selain itu juga diajarkan cara membuat alat dan pengerjaannya yang mudah serta untuk memperbaiki alat.

Pada gambar 4, menjelskan cara pembuatan dan penggunaan alat pengiris ubi. Disini semangat peserta sangat tinggi untuk ingin lebih tahu bagaimana cara membuat alat ini yang sangat sederhana tetapi sangat dimanfaatkan di Desa, khususnya untuk membuka usaha baru berupa usaha keripik ubi dan pisang. Sementara seperti terlihat pada gambar 5 peserta ingin tahu cara penggunaan alat belah buah pinang dan mereka juga ingin tahu cara membuat alat Teknologi Tepat Guna. Alat ini sangat diperluan didesa ini karena desa ini sangat banyak potensi pinang.

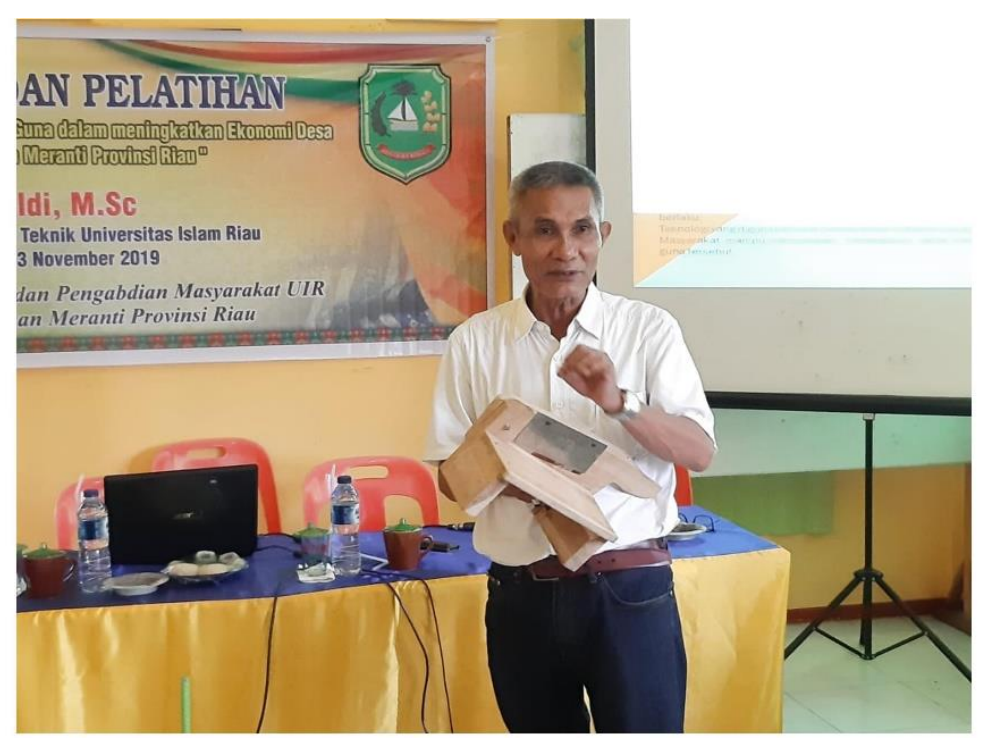

Gambar 4. Menjelaskan cara pembuatan alat pengiris ubi 


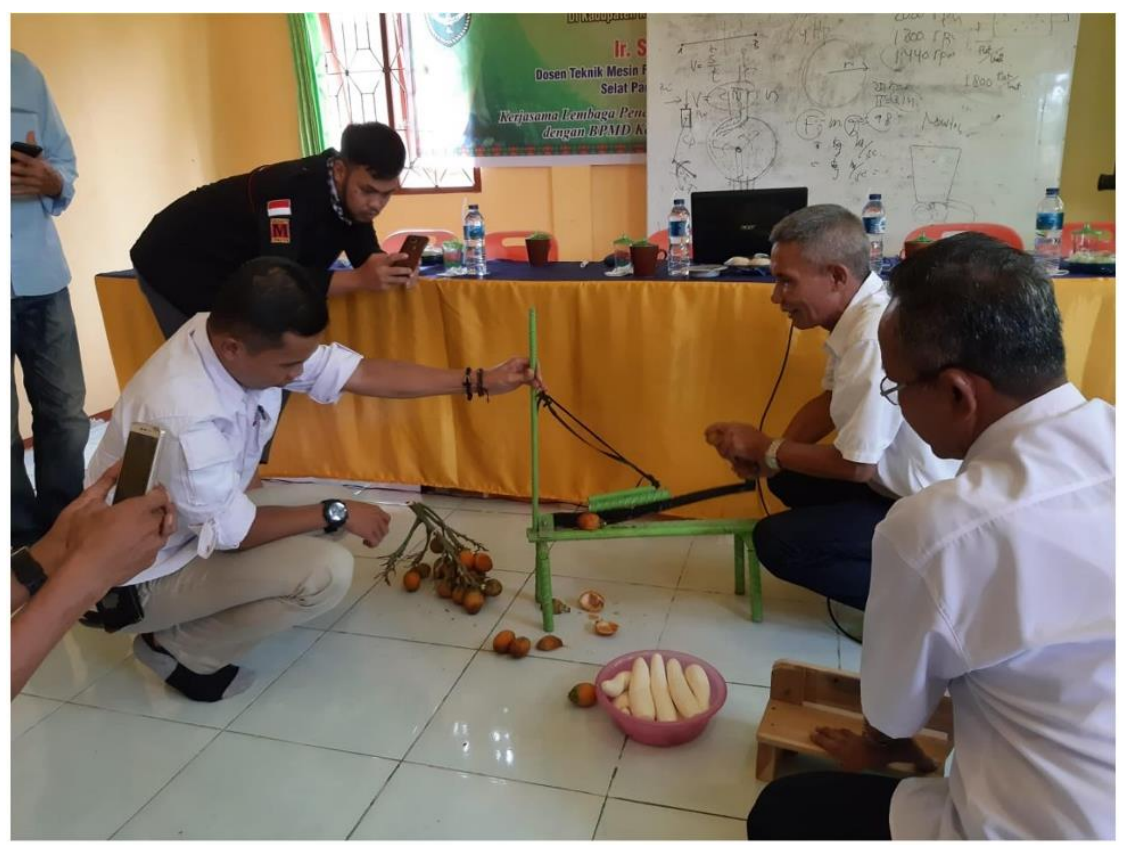

Gambar 5. Menjelaskan cara pembuatan alat pembelah buah pinang

\section{KESIMPULAN}

Dari hasil kegiatan pengabdian kepada masyarakat dapat disimpulkan bahwa penyuluhan tentang Ilmu Pengetahuan dan Teknologi Tepat Guna (TTG) dalam meningkatkan Ekonomi Desa di Desa Bina Maju Kecamatan Rangsang Barat Kabupaten Kepulauan Meranti Provinsi Riau telah dilaksanakan pada tanggal 18-20 Oktober 2019 berjalan dengan baik dan lancer. Kegiatan ini di koordinir tim dosen dan mahasiswa program studi Teknik Mesin Fakultas Teknik Universitas Islam Riau. Setelah mengikuti kegiatan pengabdian kepada masyarakat ini, ilmu pengetahuan dan pemahaman pentingnya Teknologi Tepat Guna (TTG) peserta penyuluhan yaitu anggota Pos Pelayanan Teknologi Tepat Guna Desa Bina Maju dalam hal pemahaman dan perlunya serta pembuatan Teknologi Tepat Guna (TTG). Berdasarkan evaluasi alat yang diajarkan sekarang sudah dapat dibuat sendiri dan dipasarkan disekitar daerah kecamatan Rangsang Barat yaitu alat pembelah Pinang dan Pengiris Ubi.

\section{UCAPAN TERIMA KASIH}

Terima kasih kepada Lembaga Penelitian dan Pengabdian Kepada Masyarakat (LPPM) Universitas Islam Riau yang telah memberikan dukungan dana terselenggaranya kegiatan ini melalu kontrak no. 287/PKM/KONTRAK/LPPM-UIR/11-2019

\section{DAFTAR PUSTAKA}

Arsyad, L. (1999). Pengantar perencanaan dan pembangunan ekonomi daerah. Badan Penerbitan Fakultas Ekonomi (BPFE).

Khusnawati, E., \& Prasetyo, Y. E. (2016). Difusi dan Adopsi Teknologi Tepat Guna pada Usaha Mikro, Kecil dan Menengah: Observasi pada Kegiatan IPTEKDA LIPI di Kabupaten Subang.

Rahmiyati, N. (2015). Model Pemberdayaan Masyarakat Melalui Penerapan Teknologi Tepat Guna di Kota Mojokerto. JMM17: Jurnal Ilmu Ekonomi Dan Manajemen, 2(02).

Statistik, B. P. (2019). Data dan Informasi kemiskinan kabupaten/kota tahun 2018. Jakarta: Badan Pusat Statistik. 